Web Jurnal:

http://ejournal.kemenperin.go.id/jli

\title{
Reduksi pencemar limbah cair industri tahu dengan tumbuhan melati air (Echinodorus palaefolius) dalam sistem kombinasi constructed wetland dan filtrasi
}

\section{Reduction of the pollution parameters in tofu industry wastewater by water jasmine plant (Echinodorus palaefolius) in constructed wetland and filtration combination system}

\author{
Monik Kasman ${ }^{1}$, Anggrika Riyanti ${ }^{1}$, Salmariza. $\mathrm{Sy}^{2}$, dan Muhammad Ridwan ${ }^{1}$ \\ 1 Program Studi Teknik Lingkungan, Fakultas Teknik, Universitas Batanghari \\ J1. Slamet Riyadi, Broni, Jambi, 36122, Phone/Fax. (0741)668280 \\ 2 Balai Riset dan Standardisasi Industri, Padang \\ Jln Raya LIK No 23 Ulu Gadut Padang, Indonesia \\ * e-mail: emka_engineer@yahoo.com
}

\begin{tabular}{l}
\hline ARTICLE INFO \\
\hline History of article: \\
Diterima: \\
23 April 2018 \\
Direvisi: \\
23 Juni 2018 \\
Diterbitkan: \\
28 Juni 2018
\end{tabular}

\section{Keywords:}

constructed wetland; melati air;

Echinodorus

palaefolius;

limbah cair industri tahu

\begin{abstract}
ABSTRAK
Limbah cair industri tahu mengandung bahan organik tinggi yang dapat menurunkan oksigen terlarut, mengotori, dan menimbulkan bau menyengat sehingga berpotensi mencemari perairan penerima. Constructed wetland merupakan salah satu teknologi pengolahan limbah cair yang efisien, efektif, dan tepat guna karena menggunakan keragaman vegetasi. Penelitian sistem constructed wetland menggunakan tanaman melati air (Echinodorus palaefolius) yang dikombinasikan dengan sistem filtrasi bertujuan untuk penurunan pencemar BOD, TSS, dan minyak lemak dalam limbah cair industri tahu sebagai pengaruh variasi waktu detensi. Waktu detensi meliputi 5, 7, 9, 11, 13, dan 15 hari. Hasil penelitian menunjukkan bahwa reduksi pencemar BOD, TSS, dan minyak lemak dipengaruhi oleh waktu detensi. Efisiensi reduksi BOD, TSS, dan minyak lemak meningkat dengan bertambahnya waktu detensi. Sistem kombinasi constructed wetland dan filtrasi menggunakan tumbuhan melati air efektif mereduksi parameter pencemar limbah cair industri tahu dengan efisiensi reduksi untuk BOD, TSS, dan minyak lemak berturut-turut 52-95\%, 45-67\%, dan 59-78\% dengan konsentrasi $97 \mathrm{mg} / \mathrm{L}, 40 \mathrm{mg} / \mathrm{L}$ dan $4,2 \mathrm{mg} / \mathrm{L}$ pada waktu detensi 15 hari. Hasil ini mememenuhi baku mutu limbah cair industri tahu sesuai Peraturan Menteri Lingkungan Hidup No. 5 tahun 2014.
\end{abstract}

\section{Kata kunci:}

constructed wetlands; jasmine plants

Echinodorus

palaefolius;

tofu industry

wastewater

\begin{abstract}
Tofu industry wastewater contains high organic material which reduces dissolved oxygen, contaminates water, and odor that potentially contaminates and pollutes receiving surface water. Constructed wetland is one of the recently proven efficient technologies for wastewater treatment. This is due to vegetation diversity. Constructed wetland systems have been developed using water jasmine plants combined with filtration systems for the reduction of BOD, TSS, and oil and grease in tofu wastewater as a function of detention time. Detention times were varied at 5, 7, 9, 11, 13, and 15 days. The results revealed that the reduction of BOD, TSS, and oil and grease was influenced by detention time. The reduction efficiency of BOD, TSS, and oil and grease decreased with increasing the detention time. The combined system of constructed wetland and filtration using water jasmine plants effectively reduces the pollution parameters in tofu industry wastewater with a reduction efficiency for BOD, TSS, and oil and greasel of 52$95 \%, 45-67 \%$, and $59-78 \%$ respectively with concentration of $97 \mathrm{mg} / \mathrm{L}, 40 \mathrm{mg} / \mathrm{L}$, and 4.2 $\mathrm{mg} / \mathrm{L}$ at the detention time of 15 days. This results fulfill the requirement of the liquid waste standard according to the Minister of Environment Regulation No. 5 year 2014.
\end{abstract}




\section{Pendahuluan}

Limbah cair industri tahu dihasilkan dari proses pembuatan tahu pada saat perendaman, penggumpalan, dan pengepresan. Pada umumnya, limbah cair industri tahu memiliki karakteristik berupa pH, TSS (Total Suspended Solids), COD (Chemical Oxygen Demand), BOD (Biochemical Oxygen Demand), amoniak, minyak dan lemak, nitrit, dan nitrat yang tinggi dan masih melebihi baku mutu limbah cair yang ditetapkan. Secara fisik, limbah cair industri tahu berupa cairan kental berwarna putih keruh karena tingginya kandungan padatan tersuspensi dan berbau tengik karena tingginya kandungan zat organik (Faisal et al., 2015; Rahayu et al., 2017). Proses dekomposisi zat organik oleh mikroorganisme aerob memerlukan oksigen dalam jumlah besar untuk memperoleh energi. Proses ini menurunkan konsentrasi oksigen terlarut di dalam air (Fachrurozi et al., 2010).

Kekurangan oksigen terlarut menyebabkan penguraian zat organik dilakukan oleh mikroorganisme anaerob yang mengeluarkan gas asam sulfida $\left(\mathrm{H}_{2} \mathrm{~S}\right)$ dan gas metana $\left(\mathrm{CH}_{4}\right)$ yang berbau seperti telur busuk. Tingginya konsentrasi zat organik dalam limbah cair tahu termasuk kandungan amoniak akan menyebabkan terjadinya penurunan kandungan oksigen dalam air sehingga kebutuhan oksigen biologi dan kebutuhan oksigen kimia dalam perairan tinggi (Belén et al., 2012; Ratnani, 2012).

Penelitian pengolahan limbah cair industri tahu telah banyak dilakukan. Diantaranya adalah dengan menggunakan sistem Multi Soil Layering/MSL (Sy, 2008a), menggunakan biofilter (Herlambang, 2001). Falling-film freeze(Belén et al., 2012), Sequencing Batch Reactor (Rahayu et al., 2017) dan menggunakan Constructed wetland (Fachrurozi et al., 2010; Komala et al., 2007; Nindra and Hartini, 2015; Sasono and Pungut, 2013; Sy, 2008b, 2006).

Constructed wetland (CW) merupakan lahan artifisial yang dibangun dengan memanfaatkan proses alami yang melibatkan vegetasi lahan basah (hydrophyte), tanah, dan kumpulan mikroba terkait untuk membantu dalam pengolahan air limbah secara biologi (Vymazal, 2011). CW dirancang untuk mengambil keuntungan dari banyak proses yang sama yang terjadi di lahan basah alami, tetapi melakukannya dalam lingkungan yang lebih terkendali. Mekanisme pengolahan limbah cair pada $\mathrm{CW}$ mengacu pada kemampuan tumbuhan menguraikan dan mereduksi pencemar. Secara umum konsep penguraian terdiri atas fitoekstraksi, fitovolatilisasi, fitodegradasi, fitostabilisasi, rhizofiltrasi dan intereaksi dengan mikroorganisme pengurai polutan (Sri et al., 2013; Sy, 2006; Vymazal, 2010).

Prinsip dasar sistem pengolah limbah pada CW adalah pada proses respirasi tanaman hydrophyte yang mampu mengisap oksigen dari udara melalui daun, batang, dan akarnya yang kemudian dilepaskan kembali pada daerah sekitar perakaran (rhizosphere). Hal ini dimungkinkan karena jenis tanaman hydrophyte mempunyai ruang antar sel atau lubang saluran udara (aerenchym) sebagai alat transportasi oksigen dari atmosfir ke bagian perakaran. Kelebihan lain tanaman ini adalah bisa hidup pada kondisi yang anaerob (Sri et al., 2013; Sy, 2006).

Constructed wetland dapat diimplementasikan secara insitu dan eksitu tapi memerlukan waktu detensi yang cukup lama (Vymazal, 2010). Sistem constructed wetland dinilai tepat diimplementasikan di Indonesia karena negara ini kaya akan keragaman jenis vegetasi air. Disamping itu selain $\mathrm{CW}$ praktis untuk digunakan, ia juga tepat guna, sederhana, mudah dan murah dalam pemeliharannya (Kasman et al., 2018). Beberapa penelitian yang telah melaporkan bahwa constructed wetland dapat menurunkan pencemar organik dan anorganik secara efektif diantaranya adalah dengan menggunakan tanaman mensiang (Scirpus grossus L.f), (Komala et al., 2007; Sy, 2008b, 2006), teratai (Nympahea Firecrest) (Nindra and Hartini, 2015), Eceng gondok (Ratnani, 2012), melati air (Echinodorus palaefolius) (Kasman et al., 2018; Prayitno, 2013; Sasono and Pungut, 2013), Zantedeschia aethiopica, Strelitzia reginae, Anturium andreanum, Agapanthus africanus (Zurita et al., 2009), Typha angustifolia (Weerakoon et al., 2013).

Tumbuhan melati air (Echinodorus palaefolius) merupakan tanaman hias yang dapat hidup dalam berbagai musim dan selalu membutuhkan air pada media tanamnya. Secara taksonomi, melati air dapat diklasifikasikan kedalam kingdom Plantae, famili Alismataceace, genus Echinodorus dan spesies Echinodorus Palaefolius L. (Lestari and Kencana, 2015).

Tumbuhan melati air mudah tumbuh, tidak memerlukan perawatan yang khusus dan mempunyai kemampuan menyerap dan mengurai polutan serta menurunkan kandungan polutan tersebut. Berdasarkan penelitian sebelumnya, pengolahan grey water dengan melati air pada sistem CW dengan variasi waktu detensi dan kondisi tanaman dapat menurunkan BOD dan TSS hingga $79 \%$ dan $98 \%$ secara berurut (Kasman et al., 2018). Hal ini bisa dimungkinkan karena beberapa faktor, salah satunya adalah karena sistem perakaran tanaman melati air. Sistem perakaran melati air terletak di dasar perairan, reproduksinya fleksibel, kuat, panjang dan menjalar sehingga sangat efektif dalam memperluas area tempat mikroorganisme melekat (Prayitno, 2013; Sasono and Pungut, 2013)

Implementasi CW dapat dikombinasikan dengan filtrasi untuk meningkatkan efisiensi reduksi pencemar (Vymazal, 2011). Proses filtrasi dengan menggunakan media filter alami dapat menjadi pengolahan primer untuk mengurangi beban pengolahan pencemar sebelum diolah pada sistem CW. Proses filtrasi sangat diperlukan bila konsentrasi TSS suatu limbah cair tinggi. Pada penelitian ini, pengolahan limbah cair industri tahu dilakukan pada reaktor CW yang menggunakan tanaman melati air yang dikombinasi dengan sistem filtrasi untuk mengamati efisiensi reduksi parameter pencemar limbah cair industri tahu meliputi BOD, TSS dan minyak dan lemak menggunakan sistem kombinasi $\mathrm{CW}$ dan filtrasi.

\section{Metode}

Penelitian dilakukan dengan mengamati pengaruh variabel bebas terhadap variabel terikat. Variabel bebas 
meliputi waktu detensi atau waktu tinggal limbah saat terjadi proses pengolahan pada sistem kombinasi CW dan filtrasi. Waktu detensi menentukan waktu atau lamanya proses kontak yang terjadi antara limbah dengan sistem pengolahan. Variabel terikat meliputi konsentrasi akhir pencemar BOD, TSS, dan minyak dan lemak. Konsentrasi awal dan akhir dari limbah cair industri tahu dibandingkan dan dianalisis secara deskriptif. Keefektifan reduksi BOD, TSS, dan minyak dan lemak mengacu pada efisiensi reduksi dan baku mutu pada Peraturan Menteri Lingkungan Hidup (PerMen LH) No 5 tahun 2014 tentang baku mutu limbah cair industri.

\subsection{Alat dan bahan}

Reaktor constructed wetland $(\mathrm{CW})$ terdiri dari bak filtrasi dan constructed wetland dengan aliran bawah permukaan (sub surface flow wetland/SSF Wetland) yang terbuat dari kaca. Bak filtrasi mempunyai dimensi dengan panjang $50 \mathrm{~cm}$, lebar $30 \mathrm{~cm}$, dan tinggi $30 \mathrm{~cm}$, dilapisi media filter yang terdiri atas pecahan genteng dan ketebalan $6 \mathrm{~cm}$; karbon aktif dengan ketebalan $5 \mathrm{~cm}$; pasir silika dengan ketebalan $5 \mathrm{~cm}$; dan batu zeolit dengan ketebalan $5 \mathrm{~cm}$. Bak filtrasi berfungsi sebagai bak kontrol dan bak pra pengolahan limbah cair sebelum bak sub surface flow wetland. Bak sub surface flow wetland mempunyai panjang 1 meter, lebar $30 \mathrm{~cm}$, dan tinggi $30 \mathrm{~cm}$. Lapisan dasar dilapisi batu pecah dengan ketebalan $6 \mathrm{~cm}$, lapisan kedua (atas) adalah tanah humus dengan ketebalan $15 \mathrm{~cm}$. Lapisan atas ditanami melati air (Echinodorus palaefolius). Instalasi dilengkapi dengan bak penampung sebagai tempat homogenisasi limbah cair industri tahu. Waktu detensi sangat dipengaruhi oleh permeabilitas dan konduktivitas hidrolis media (Prayitno, 2013). Waktu detensi mempengaruhi efisiensi dan efektifitas pengolahan karena menentukan lamanya kontak antara mikroorganisme dengan limbah cair, serta oksigen yang dikeluarkan oleh akar tanaman. Susunan reaktor constructed wetland dapat dilihat pada Gambar 1.

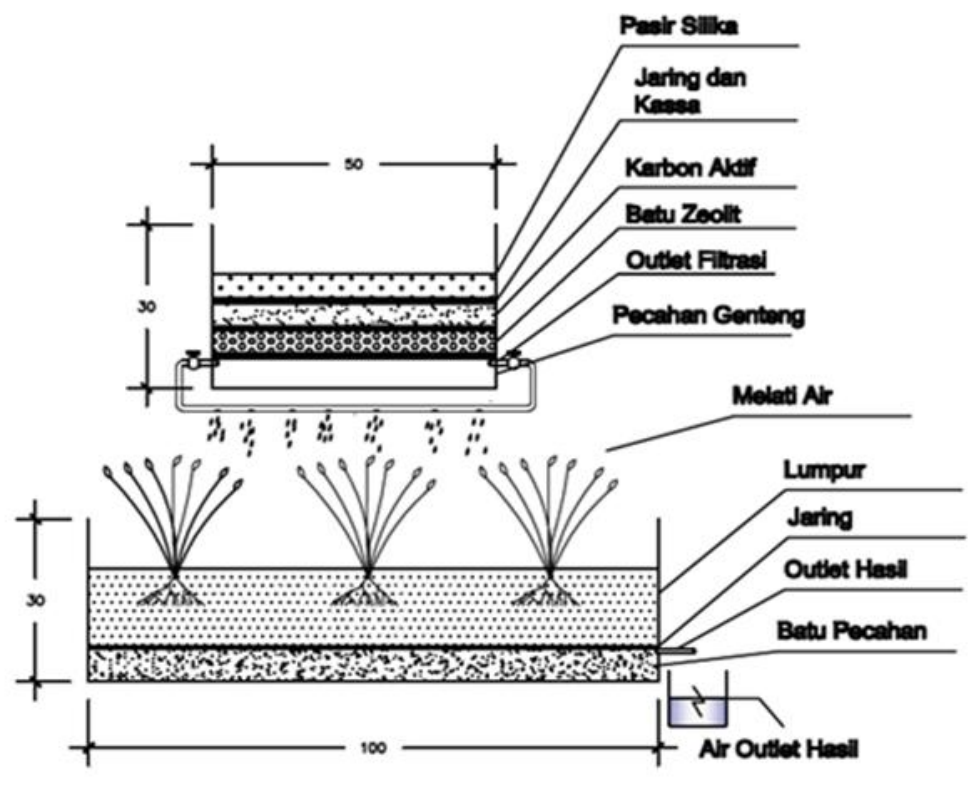

TAMPAR DEPAN

Gambar 1. Reaktor constructed wetland $(\mathrm{CW})$

\subsection{Penanaman dan aklimatisasi melati air}

Penanaman melati air dilakukan dalam pot-pot tanaman dengan memilih tanah humus sebagai media tumbuh. Kondisi media tanam dijaga tetap lembab dan basah. Secara teoritis, melati air tumbuh lebih subur di lingkungan yang lembab dan basah. Reaktor CW ditempatkan di luar ruangan (outdoor) dengan cahaya matahari yang cukup. Setelah melati air tumbuh subur, tanaman dipindahkan ke instalasi reaktor $\mathrm{CW}$ dan instalasi dilengkapi dengan bak penampung limbah, bak penampung air olahan (outlet), dan perpipaan. Sebelum limbah cair industri tahu dialirkan, tanaman melati air dalam sistem CW diaklimatisasi sebagai tahap adaptasi tanaman dengan limbah dan mencegah terjadinya shock loading. Pada tahap ini, melati air beradaptasi dengan sifat dan karakteristik limbah cair industri tahu dan lingkungan hidupnya. Aklimatisasi dilakukan selama 2 bulan.

\subsection{Eksperimen}

Eksperimen dilakukan dengan memvariasikan waktu detensi. Waktu detensi limbah cair industri tahu dalam reaktor constructed wetlands, meliputi, 5, 7, 9, 11, 13, dan 15 hari. Pengamatan dilakukan untuk melihat 
pengaruh variabel bebas terhadap variabel terikat yaitu BOD (Biochemical Oxygen Demand), (TSS (Total Suspended Solid) dan minyak lemak sebagai parameter pencemar yang terkandung dalam limbah cair industri tahu, mengacu pada PerMen LH No 5 tahun 2014.

Sampel limbah cair industri tahu berasal dari efluen Pabrik tahu Sri Rezeki, Daerah Talang Banjar, Kecamatan Jambi Timur. Sampel limbah cair industri tahu diambil dan dimasukkan dalam bak penampung limbah. Sampel diambil dengan metoda grab sampling, selama tiga hari berturut-turut, kemudian dimasukkan dalam bak penampung awal (inlet reaktor). Sampel dihomogenkan dengan diaduk secara manual sebelum masuk ke reaktor CW. Sampel di bak penampung limbah dialirkan kontinyu secara kaskade ke dalam bak reaktor menggunakan pipa pvc. Debit dan kecepatan aliran diatur berdasarkan waktu detensi dengan mengatur katup/ valve (kran inlet). Pengaliran sampel dilakukan selama 15 hari. Sampel air olahan (outlet) diambil pada hari ke-5, ke-7, ke-9, ke-11, ke-13 dan ke15, yang disebut dengan waktu detensi. Sampel uji dikumpulkan dari inlet (sebelum diolah), outlet bak filtrasi dan outlet bak constructed wetland. Pengujian sampel mengacu pada SNI 6989.72 - 2009 (BOD),
SNI.06-6989.3-2004 (TSS) dan SNI 06-6989.15-2004 (minyak lemak).

\section{Hasil dan pembahasan}

\subsection{Karakteristik limbah cair industri tahu}

Secara visual sampel limbah cair industri tahu berwarna putih keruh dengan endapan dan berbau menyengat. Karakterisasi limbah cair industri tahu dengan konsentrasi pencemarnya disajikan pada Tabel 1 . Dari Tabel 1 terlihat bahwa limbah tahu bersifat asam, dengan $\mathrm{pH}$ rata-rata 3,827. Selain $\mathrm{pH}$ yang tidak memenuhi baku mutu, terlihat juga bahwa limbah cair industri tahu memiliki tingkat pencemar organik yang tinggi dengan nilai BOD, COD, TSS dan minyak dan lemak berturut-turut mencapai $726-1929 \mathrm{mg} / \mathrm{L}, 1474$ - $2258 \mathrm{mg} / \mathrm{L}, 128$ - 352mg/L dan 19 - $28 \mathrm{mg} / \mathrm{L}$ yang telah melewati baku mutu yang ditentukan. Hal ini diperkirakan karena bahan baku yang digunakan adalah kedele yang kaya akan protein dan zat organik, serta penggunaan asam asetat dalam proses pembuatan tahu yang menyebabkan limbah tersebut menjadi asam (Sy, 2008a).

Tabel 1.

Konsentrasi parameter pencemar limbah cair industri tahu

\begin{tabular}{lllll}
\hline \multirow{2}{*}{ Parameter } & Satuan & \multicolumn{2}{l}{ Konsentrasi } & Baku Mutu * \\
\cline { 3 - 4 } $\mathrm{pH}$ & - & 3,827 & $3,77-3,87$ & $6-9$ \\
$\mathrm{BOD}$ & $\mathrm{mg} / \mathrm{L}$ & 1093,167 & $726-1929$ & 150 \\
$\mathrm{COD}$ & $\mathrm{mg} / \mathrm{L}$ & 1735,333 & $1474-2258$ & 300 \\
TSS & $\mathrm{mg} / \mathrm{L}$ & 237,500 & $128-352$ & 200 \\
Minyak \& Lemak & $\mathrm{mg} / \mathrm{L}$ & 22,167 & $19-28$ & 10 \\
\hline
\end{tabular}

*PerMen LH No 5 tahun 2014 (KLH, 2014)

Tingginya konsentrasi BOD dan COD juga menunjukkan tingginya aktivitas mikroorganisme dalam limbah cair industri tahu sehingga akan menurunkan jumlah oksigen terlarut dalam air. Konsentrasi TSS dan minyak lemak yang tinggi juga akan menyebabkan limbah cair industri tahu sangat keruh dan berlendir/berbusa.

\subsection{Pengaruh waktu detensi terhadap parameter pencemar}

Pengolahan limbah cair secara biologi, dengan sistem constructed wetland sangat dipengaruhi oleh waktu detensi atau waktu tinggal (Vymazal, 2011, 2010). Semakin lama waktu detensi, semakin rendah konsentrasi pencemar dan semakin tinggi efisiensi reduksi. Pengaruh waktu detensi terhadap persentase reduksi dan konsentrasi BOD, TSS dan minyak lemak air limbah tahu yang diolah dengan kombinasi sistem CW dan filtrasi disajikan pada Gambar 2 dan 3. Dari
Gambar 2 terlihat bahwa efisiensi reduksi untuk BOD, TSS dan minyak lemak didapatkan berturut-turut 52$95 \%$, 45-67\% dan 59-78\%. Waktu detensi 15 hari memberikan efisiensi reduksi tertinggi dengan konsentrasi $97 \mathrm{mg} / \mathrm{L}, 40 \mathrm{mg} / \mathrm{L}$ dan 4,2 mg/L untuk BOD, TSS dan minyak lemak (Gambar 3) yang dapat mememenuhi sampai di bawah baku mutu limbah cair industri tahu PerMen LH No 5 tahun 2014.

Dari Gambar 2 juga dapat dilihat kecenderungan efisiensi reduksi BOD lebih tinggi dinadingkan dengan minyak lemak dan TSS. Efisiensi reduksi mencapai $95 \%, 78 \%$ dan $67 \%$ berturut-turut untuk BOD, minyak lemak dan TSS. Lebih tingginya reduksi BOD kemungkinan disebabkan karena proses penguraian zat organik lebih banyak terjadi pada daerah perakaran oleh mikroorganisme dengan menanfaatkan oksigen yang diserap dari udara melalui batang, daun batang, akar dan rhizome tumbuhan melati air. Sementara itu minyak lemak, TSS lebih sulit diuraikan dibandingkan zat 
organik dan kemungkinan sebagian hanya terserap dalam lapisan tanah dan sebagian lolos bersama aliran outlet.

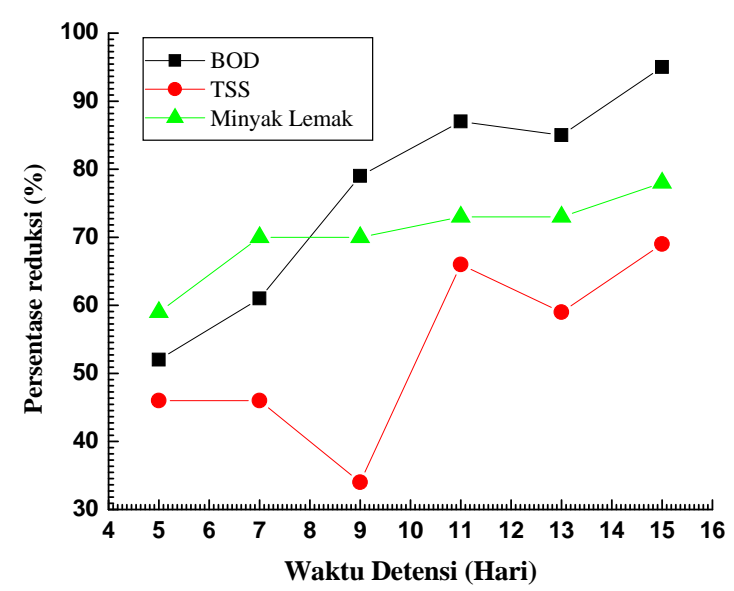

Gambar 2. Pengaruh waktu detensi terhadap persentase reduksi BOD, TSS dan minyak lemak air limbah industri tahu yang diolah dengan tumbuhan melati air

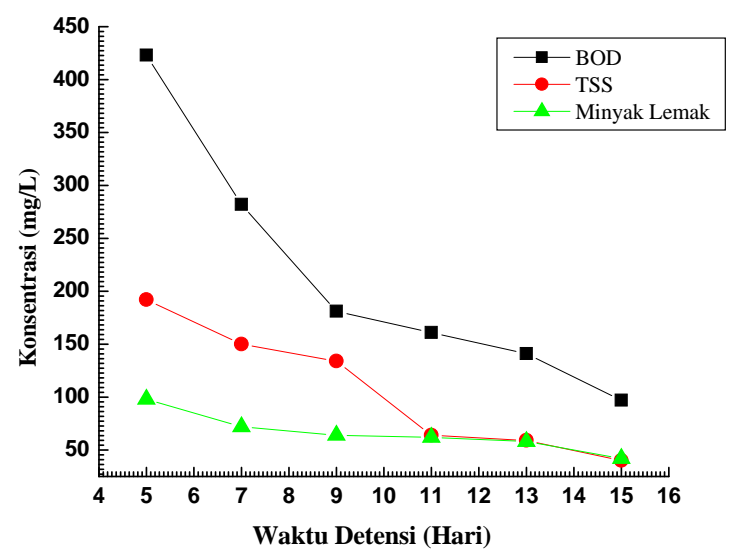

Gambar 3. Pengaruh waktu detensi terhadap Konsentrasi BOD, TSS dan minyak lemak air limbah industri tahu yang diolah dengan tumbuhan melati air

\subsection{Biochemical Oxygen Demand (BOD)}

Pengaruh waktu detensi terhadap konsentrasi BOD limbah industri tahu sebelum dan sesudah diolah dengan tumbuhan melati air dapat dilihat pada Gambar 4. Konsentrasi BOD limbah cair industri tahu sangat tinggi dan melebihi baku mutu PerMen LH No 5 tahun 2014. Kombinasi system filtrasi dengan CW sangat membantu penurunan BOD. Konsentrasi BOD, mulai menurun saat limbah cair diolah di bak filtrasi, dan semakin menurun setelah diolah di bak CW. Dari Gambar 3 terlihat bahwa waktu detensi berpengaruh terhadap penurunan konsentrasi BOD. Semakin lama waktu destensi, maka semakin rendah konsentrasi BOD pada outlet CW. Penurunan konsentrasi BOD pada hari ke-5 sampai hari ke 11 terlihat masih diberada diatas baku mutu yaitu 423 $-161 \mathrm{mg} / \mathrm{L}$. namun pada hari ke 13 sudah dapat memenuhi baku mutu yaitu menjadi $141 \mathrm{mg} / \mathrm{L}$ dan semakin menurun pada ke-15 menjadi $97 \mathrm{mg} / \mathrm{L}$. System kombinasi constructed wetland dan filtrasi ini terbukti efektif untuk menurunkan konsentrasi BOD.

Terjadinya penurunan konsentrasi BOD dari limbah tahu yang diolah dengan $\mathrm{CW}$ disebabkan karena keberadaan mikroorganisme pada system perakaran tanaman melati air saat terjadinya proses oksidasi oleh bakteri aerob yang tumbuh di sekitar rhizosphere tanaman melati air dan bakteri heterotrof dalam air limbah. Penyisihan BOD terjadi melalui proses kimia dan biologi yang kompleks antara media material tanah dan batuan, tanaman dan mikroorganisme. Tanaman melati air mendapatkan bahan organik sebagai nutrisi melalui proses dekomposisi bahan organik oleh jaringan akarnya. Bahan organik merupakan nutrisi dalam bentuk karbon, nitrogen dan energi.

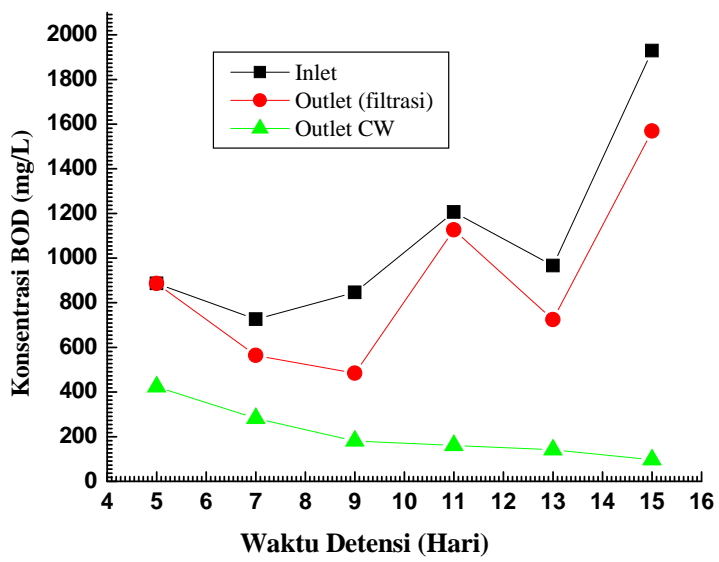

Gambar 4. Pengaruh waktu detensi terhadap konsentrasi BOD, limbah industri tahu sebelum dan sesudah diolah dengan tumbuhan melati air

Penyediaan oksigen terjadi melalui proses fotosintesis. Akar tumbuhan di bawah permukaan air mengeluarkan oksigen dan membentuk zona rizosfer yang kaya oksigen. Oksigen dialirkan ke akar melalui batang secara difusi pada pori-pori daun. Oksigen yang dilepaskan oleh akar tanaman air menyebabkan air dan tanah disekitar rambut akar memiliki oksigen terlarut yang lebih tinggi dibandingkan dengan air dan tanah yang tidak ditumbuhi tanaman air, sehingga memungkinkan organisme pengurai seperti bakteri aerob dapat hidup dalam lingkungan lahan basah yang berkondisi anaerob (Fachrurozi et al., 2010; Prayitno, 2013; Sri et al., 2013; Vymazal, 2011, 2010)

\subsection{Total Suspended Solid (TSS)}

Pengaruh waktu detensi terhadap konsentrasi TSS limbah industri tahu sebelum dan sesudah diolah dengan tumbuhan melati air dapat dilihat pada Gambar 5. Konsentrasi awal TSS limbah cair industri tahu melebihi baku mutu air limbah industri tahu pada PerMen LH No 5 tahun 2014 (Tabel 1) yaitu $200 \mathrm{mg} / \mathrm{L}$. Konsentrasi TSS air limbah tahu menyatakan banyaknya zat padat tersuspensi dalam air limbah tahu berupa partikel yang tidak larut yang dapat berasal dari proses pencucian, perebusan, penyaringan dan pengepresan kacang kedelei dan dapat menyebabkan kekeruhan. Partikel TSS yang 
kasar dapat disisihkan dengan metoda filtrasi. Sedangkan partikel yang halus yang lolos dari bak filtrasi yang bersifat organik akan membentuk sedimentasi pada bagian dasar bak $\mathrm{CW}$ dan akan didekomposisi oleh mikroba yang berada pada bagian perakaran tanaman melati air.

Dari Gambar 5 terlihat bahwa proses filtrasi sangat membantu menurunkan konsentrasi TSS sampai dibawah baku mutu. Terlihat bahwa TSS pada bak filtrasi berkisar $116 \mathrm{mg} / \mathrm{L}$ pada hari ke 7 dan menurun menjadi $59 \mathrm{mg} / \mathrm{L}$ pada hari ke15. TSS Hasil pengujian pada bak CW dengan tanaman melati air memperlihatkan penurunan konsentrasi TSS dipengaruhi oleh lamanya waktu detensi. Konsentrasi TSS makin menurun seiring dengan bertambahnya waktu detensi yaitu dari $192 \mathrm{mg} / \mathrm{L}$ pada hari ke 5 menjadi $40 \mathrm{mg} / \mathrm{L}$ pada hari ke 15 dan dapat memenuhi baku mutu untuk semua perlakuan waktu detensi.

Penurunan TSS setelah proses pengolahan dengan menggunakan melati air disebabkan karena porositas media filter tanaman melati air, terjadi proses penyerapan oleh tanaman, dekomposisi bahan organik terlarut dan mengendapnya hasil dekomposisi bahan organik (Fachrurozi et al., 2010; Vymazal, 2010). Mikroorganisme dan akar serabut tanaman melati air juga diduga berperan dalam penyerapan/penyaringan TSS, sehingga dapat menurunkan kandungan TSS. Bentuk serabut akar memungkinkan koloid menempel pada akar-akar tersebut. Penurunan TSS akan berpengaruh pada penurunan konsentrasi BOD dan minyak lemak (Fachrurozi et al., 2010; Komala et al., 2007; Sy, 2008b; Vymazal, 2011, 2010).

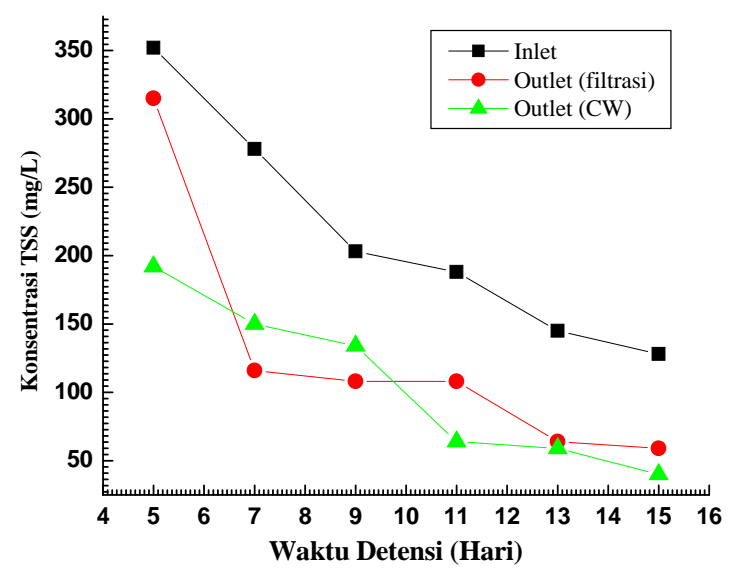

Gambar 5. Pengaruh waktu detensi terhadap konsentrasi TSS limbah industri tahu sebelum dan sesudah diolah dengan tumbuhan melati air

\subsection{Minyak lemak}

Minyak dan lemak merupakan senyawa trigliserida dari gliserol. Konsentrasi minyak lemak air baku limbah cair industri tahu rata-rata yakni $22,167 \mathrm{mg} / \mathrm{L}$ dan masih melebihi dari baku mutu yang telah ditentukan oleh PerMen LH No 5 tahun 2014 yaitu 10 mg/L. Pengaruh waktu detensi terhadap konsentrasi minyak lemak limbah industri tahu sebelum dan sesudah diolah dengan tumbuhan melati air dapat dilihat pada Gambar 6. Sama halnya dengan TSS, penurunan konsentrasi minyak lemak juga telah dibantu oleh proses filtrasi sehingga sampai memenuhi baku mutu yang ditetapkan (Gambar 6). Penurunan konsentrasi kandungan minyak lemak pada bak CW dengan tanaman melati air sejalan dengan waktu detensi. Semakin lama waktu detensi, maka semakin rendah konsentrasi minyak lemak. Hal ini diduga karena terjerapnya minyak pada media tumbuh reaksi aktivitas metabolisme oleh mikroorganisme pada tanaman melati air dan akar tanaman melati air.

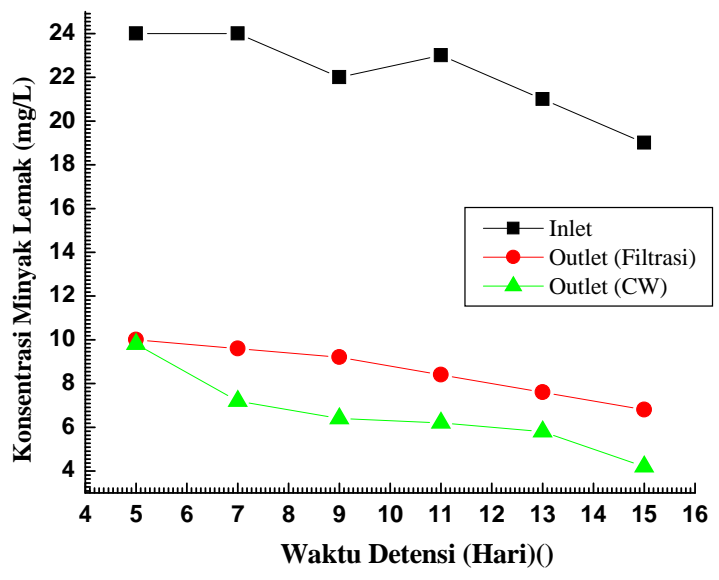

Gambar 6. Pengaruh waktu detensi terhadap konsentrasi minyak lemak limbah industri tahu sebelum dan sesudah diolah dengan tumbuhan melati air

\subsection{Perbandingan efisiensi $\mathrm{CW}$ dengan berbagai jenis tanaman}

Banyak penelitian penggunaan $\mathrm{CW}$ dengan berbagai jenis tanaman untuk pengolah air limbah telah dilaporkan. Efisiensinya dapat dibandingkan dengan melihat keberhasilannya. Kebanyakan penelitian menunjukkan bahwa sistem dengan tanaman mencapai efisiensi pengolahan yang tinggi. Vegetasi memiliki efek positif, dimana dapat mendukung efisiensi pengolahan yang lebih tinggi terutama untuk limbah bersifat organik yang ditentukan oleh kebutuhan oksigen biokimia dan permintaan oksigen kimia (BOD, COD) dan nutrisi seperti total nitrogen(TN), nitrogen amonia (NH4-N), dan total fosfor (TP). Hal ini dapat dijelaskan oleh peningkatan pasokan oksigen ke rizosfer melalui akar tanaman. Perbandingan efisiensi CW dengan berbagai jenis tumbuhan pada beragam air limbah ditampilkan pada Tabel 2. 
Tabel 2

Perbandingan efisiensi CW dengan berbagai jenis tumbuhan pada beragam air limbah

\begin{tabular}{|c|c|c|c|c|}
\hline Vegetasi & Jenis Air Limbah & Parameter & Efisiensi & Referensi \\
\hline Scirpus grossus L.f & $\begin{array}{l}\text { limbah cair industri crumb } \\
\text { ubber }\end{array}$ & $\begin{array}{l}\text { BOD } \\
\text { COD } \\
\text { TSS } \\
\text { Amoniak Total } \\
\text { N Total }\end{array}$ & $\begin{array}{l}95-98 \% \\
89-97 \%, \\
80-92 \%, \\
84-92 \% \\
86-93 \%\end{array}$ & (Sy, 2006) \\
\hline Scirpus grossus L.f & $\begin{array}{l}\text { limbah cair industri karet } \\
\text { remah }\end{array}$ & $\begin{array}{l}\text { BOD } \\
\text { COD } \\
\text { TSS } \\
\text { NH3 } \\
\text { total nitrogen }\end{array}$ & $\begin{array}{l}98-99 \% \\
96-98 \% \\
89-97 \% \\
93-95 \% \\
81-95 \%\end{array}$ & (Komala et al., 2007) \\
\hline $\begin{array}{l}\text { Zantedeschia aethiopica } \\
\text { Strelitzia reginae } \\
\text { Anturium andreanum } \\
\text { Agapanthus africanus }\end{array}$ & Air Limbah domestik & $\begin{array}{l}\text { BOD } \\
\text { COD } \\
\text { Org-N } \\
\text { NH4 } \\
\text { Total-P } \\
\text { TC }\end{array}$ & $\begin{array}{l}>80 \% \\
>80 \% \\
50.6 \% \\
72.2 \% \\
50 \% \\
96.9 \%\end{array}$ & (Zurita et al., 2009) \\
\hline Eceng gondok & Air limbah industri tahu & COD & & (Ratnani, 2012) \\
\hline Typha angustifolia & $\begin{array}{l}\text { Air limbah dengan lumpur } \\
\text { septik tank }\end{array}$ & $\begin{array}{l}\text { BOD5 } \\
\text { TSS) } \\
\text { fecal coliform } \\
\text { total coliform (TC), }\end{array}$ & $\begin{array}{l}80 \% \\
44 \% \\
96.5 \% \\
96.1 \%\end{array}$ & $\begin{array}{l}\text { (Weerakoon et al., } \\
\text { 2013) }\end{array}$ \\
\hline Echinodorus palaefolius & $\begin{array}{l}\text { Air limbah industri } \\
\text { penyamakan kulit }\end{array}$ & $\begin{array}{l}\text { BOD } \\
\text { COD }\end{array}$ & $\begin{array}{l}61 \% \\
69 \%\end{array}$ & (Prayitno, 2013) \\
\hline Echinodorus palaefolius & air limbah puskesmas & $\begin{array}{l}\text { BOD } \\
\text { COD }\end{array}$ & $\begin{array}{l}92 \% \\
92 \%\end{array}$ & $\begin{array}{l}\text { (Sasono and Pungut, } \\
2013 \text { ) }\end{array}$ \\
\hline Equisetum hymale & air limbah puskesmas & $\begin{array}{l}\text { BOD } \\
\text { COD }\end{array}$ & $\begin{array}{l}86 \% \\
84 \%\end{array}$ & $\begin{array}{l}\text { (Sasono and Pungut, } \\
\text { 2013) }\end{array}$ \\
\hline Echinodorus palaefolius & grey water & $\begin{array}{l}\text { BOD } \\
\text { TSS }\end{array}$ & $\begin{array}{l}72 \% \\
98 \%\end{array}$ & (Kasman et al., 2018) \\
\hline Echinodorus palaefolius & Air limbah industri tahu & $\begin{array}{l}\text { BOD } \\
\text { TSS } \\
\text { Minyak lemak }\end{array}$ & $\begin{array}{l}52-95 \% \\
45-67 \% \\
59-78 \%\end{array}$ & Pada penelitian ini \\
\hline
\end{tabular}

\section{Kesimpulan}

Sistem kombinasi constructed wetland dan filtrasi menggunakan tumbuhan melati air terbukti efektif dalam mereduksi parameter pencemar limbah cair industri tahu dengan efisiensi reduksi BOD, TSS dan minyak lemak berturut-turut $52-95 \%$, 46-69\% dan 59-79\%. Reduksi pencemar BOD, TSS dan minyak lemak sangat dipengaruhi waktu detensi (waktu tinggal). Konsentrasi BOD, TSS dan minyak lemak pada outlet CW menurun dengan bertambahnya waktu detensi. Waktu detensi optimum didapatkan pada hari ke 15 dengan konsentrasi BOD, TSS dan minyak lemak secara berurut berkisar 97 $\mathrm{mg} / \mathrm{L}, \quad \mathrm{mg} / \mathrm{L} 40 \mathrm{mg} / \mathrm{L}$ dan $4,2 \mathrm{mg} / \mathrm{L}$ yang dapat memenuhi baku mutu sesuai Peraturan Menteri Lingkungan Hidup No. 5 tahun 2014.

\section{Ucapan terima kasih}

Penulis mengucapkan apresiasi dan terima kasih pada Lembaga Penelitian dan Pengabdian Pada Masyarakat (LPPM) Universitas Batanghari yang telah mendanai penelitian ini melalui skim penelitian kompetitif dana rutin Universitas Batanghari Tahun Anggaran 2017.

\section{Daftar pustaka}

Belén, F., Sánchez, J., Hernández, E., Auleda, J.M., Raventós, M., 2012. One option for the management of wastewater from tofu production: Freeze concentration in a falling-film system. J. Food Eng. 110, 364-373. doi:10.1016/j.jfoodeng.2011.12.036

Fachrurozi, M., Utami, L.B., Suryani, D., 2010. Pengaruh variasi biomassa pistia stratiotes 1 . terhadap penurunan kadar BOD, COD, Dan TSS limbah cair tahu di Dusun Klero Sleman Yogyakarta. J. Kesehat. Masy. 4, 1-15. doi:10.12928/kesmas.v4i1.1100

Faisal, M., Mulana, F., Gani, A., Daimon, H., 2015. Physical and chemical properties of wastewater discharged from tofu industries in Banda Aceh City, Indonesia. Res. J. Pharm. Biol. Chem. Sci. 6, 1053 1058.

Herlambang, A., 2001. Pengaruh pemakaian biofilter struktur sarang tawon pada pengolah limbah organik sistem kombinasi anaerob-aerob (studi kasus : limbah tahu dan tempe). J. Teknol. Lingkung. 2, 28-36. doi:10.29122/JTL.V2I1.195

Kasman, M., Herawati, P., Aryani, N., 2018. Pemanfaatan tumbuhan melati air (Echinodorus palaefolius) dengan sistem constructed wetlands untuk pengolahan grey water. J. Daur Lingkung. 1, $10-15$.

KLH, 2014. Peraturan Menteri Lingkungan Hidup Republik Indonesia nomor 5 tahun 2014 tentang baku mutu air limbah. Kementrian Lingkungan Hidup, Jakarta.

Komala, P.S., Salmariza Sy, Murti, N., 2007. Peran media pendukung perlit dalam pengolahan limbah 
cair industri karet menggunakan tumbuhan mensiang (Scirpus Grossus L.F) (studi kasus: limbah cair industri karet remah PT. Batang Hari Barisan Padang. Bionatura 9, 258-278.

Lestari, G., Kencana, I.K., 2015. Tanaman Hias; Lanskap, 1st ed. Penebar Swadaya, Jakarta.

Nindra, D.Y., Hartini, E., 2015. Efektivitas tanaman teratai (Nympahea firecrest) dan eceng gondok (Eichhornia crassipes) dalam menurunkan kadar biochemical oxygen demand) pada limbah cair industri tahu. VISIKES J. Kesehat. Masy. 14, 123130.

Prayitno, P., 2013. Pengurangan COD dan BOD limbah cair terolah industri penyamakan kulit menggunakan taman tanaman air dengan tanaman melati air. Maj. Kulit, Karet, dan Plast. 29, 37-42. doi:10.20543/mkkp.v29i1.217

Rahayu, S.S., Purwanto, ., Budiyono, ., 2017. Effect of temperature, sludge, total suspended solids (TSS) on biogas production in tofu wastewater treatment using AnSBR reactor. Adv. Sci. Lett. 23, 2468-2471. doi:10.1166/asl.2017.8752

Ratnani, R.D., 2012. Kemampuan kombinasi eceng gondok dan lumpur aktif untuk menurunkan pencemaran pada limbah cair industri tahu. Momentum 8, 1-5.

Sasono, E., Pungut, 2013. Penurunan kadar BOD dan COD air limbah UPT puskesmas janti Kota Malang dengan metode contructed wetland. J. Tek. WAKTU 11, 60-70.

Sri, A.C., Suswati, P., Wibisono, D.G., 2013. Pengolahan limbah domestik dengan teknologi taman tanaman air (constructed wetlands). Indones. Green Technol. J. 2, 70-77.
Sy, S., 2008a. Pengaruh variasi tingkat beban organik dan laju alir terhadap efisiensi pengolahan air limbah industri tahu dengan reaktor MSL. Bul. BIPD XVI, 9-19.

Sy, S., 2008b. Kemampuan tumbuhan menslang (Scirpus Grossus L.T) dalam mereduksi parameter pencemar air limbah hotel. Bul. BIPD XVI, 30-41.

Sy, S., 2006. Penggunaan sistem pflanzenklaranlage untuk meminimalisir limbah cair industri crumb rubber. Bul. BIPD XIV, 43-56.

Vymazal, J., 2011. Plants used in constructed wetlands with horizontal subsurface flow: a review. Hydrobiologia 674, 133-156. doi:10.1007/s10750011-0738-9

Vymazal, J., 2010. Constructed wetlands for wastewater treatment. Water 2, 530-549. doi:10.3390/w2030530

Weerakoon, G.M.P.R., Jinadasa, K.B.S.N., Herath, G.B.B., Mowjood, M.I.M., van Bruggen, J.J.A., 2013. Impact of the hydraulic loading rate on pollutants removal in tropical horizontal subsurface flow constructed wetlands. Ecol. Eng. doi:10.1016/j.ecoleng.2013.09.016

Zurita, F., De Anda, J., Belmont, M.A., 2009. Treatment of domestic wastewater and production of commercial flowers in vertical and horizontal subsurface-flow constructed wetlands. Ecol. Eng. 35, 861-869. doi:10.1016/j.ecoleng.2008.12.026 